\title{
EVOLUÇÃO HISTÓRICA DO PRINCÍPIO DO DEVIDO PROCESSO LEGAL
}

João Gualberto Garcez, Ramos*

RESUMO: O princípio do devido processo legal nasceu na Inglaterra, no ano 1215. Teve um desenvolvimento diferente na Inglaterra e nos Estados Unidos da América, especialmente por causa do papel da Suprema Corte norte-americana. O devido processo legal também está no coração do Direito brasileiro desde o seu início. A Constituição do Império, de 1824, em seu art. 179, inciso II, trazia um aspecto substancial do princípio. A Constituição brasileira de 1988 apenas o enfatizou em nosso ordenamento jurídico.

\section{DELIMITAÇÃO DO TEMA}

Pode-se dizer sem medo que já faz muito tempo que o princípio do devido processo legal se encontra no centro do nosso sistema processual. Ele é a verdadeira e própria essência do processo, em todas as suas manifestações. O processo legítimo, justo, equilibrado, é o devido processo legal. Daí que todas as irregularidades do processo

* Professor Adjunto da UFPR. Procurador da República.

\begin{abstract}
The Due Process of Law was born in England, in the year 1215. It had a different development in England and in the United States of America, especially because the role of the American Supreme Court. Also, the Due Process of Law is in the core of the Law in Brasil since the very beginning. In the second half of the eighth century, many classics of the Brasilian Law wrote about it. The 1824 Brasilian Imperial Constitution, in its art. 179, inc. II, had a substantial vision of the standard. The 1988 Brasilian Constitution just stressed it.
\end{abstract}

que conspurcam esse equilíbrio, essa justeza intrínseca, violam o princípio do devido processo legal. E, "puxando a sardinha” para o nosso lado, posso afirmar que essas irregularidades são muito mais graves quando atingem o processo penal.

Essa visão corresponde ao que já escreviam processualistas antigos.

Na obra clássica de José Antonio Pimenta Bueno, por exemplo, está escrito:

As formalidades dos atos e termos do processo são frutos da prudência e razão calma da lei. 
É de muita importância que a luta que se estabelece entre o acusado e o Poder Público não sofra outra influência ou direção que não seja dela.

Os termos e condições que a lei prescreve, são meios protetores que garantem a plenitude da acusação e da defesa: são faróis que assinalam a linha e norte que os magistrados e as partes devem seguir, precauções salutares que encadeiam o arbítrio e os abusos, que esclarecem a verdade, e dão autenticidade ou valor legal aos atos. O seu fim é conciliar o interesse da justiça repressiva com a proteção devida à inocência que pode existir.

Até na "Praxe Brasileira" do conselheiro Joaquim Ignácio Ramalho, insuspeito praxista, encontram-se, aqui e ali, exortações ao respeito às formas processuais e ao direito de defesa. ${ }^{2}$

O senador do Império Vicente Alves de Paula Pessoa, também ele um praxista tardio, escreveu ser fundamental a sabedoria e o equilíbrio dos juízes, a fim de garantir que suas "decisões, conscienciosamente inspiradas e ditadas pelo único respeito das leis, sejam acatadas pelos cidadãos e invioláveis para o poder: Tribunais acessíveis a todos, permitindo a acusação e a defesa com completa liberdade, e garantias da publicidade". 3

Para Antônio Luiz da Câmara Leal, outro antigo processualista, "a forma processual representa uma garantia de direitos, tanto para

${ }^{1}$ BUENO, José Antonio Pimenta. Apontamentos sobre o Processo Criminal brasileiro, ed. anot., atual. e compl. por José Frederico Marques, facsimilar à ed. de 1857. São Paulo: Revista dos Tribunais, 1959, p. 228.

${ }^{2}$ RAMALHO, Joaquim Ignácio. Praxe brasileira, São Paulo: 1869, pp. 5, 8, 51, 52 etc.

${ }^{3}$ PESSOA, Vicente Alves de Paula. Código do Processo Criminal, 1880, p. 20. a sociedade que acusa, como para o acusado que se defende". ${ }^{4}$

Todas essas passagens se referem, com maior ou menor grau de penetração, ao Devido Processo Legal, enquanto garantidor das formas processuais.

Essa visão, portanto, não se constitui em novidade alguma no Brasil.

Ocorre que, sobretudo a partir da Constituição de 1988, surgiram novas interpretações desse secular princípio. De uma hora para outra, vieram à baila expressões extravagantes como "razoabilidade das leis" para, com base nelas, impugnar-se a constitucionalidade de normas jurídicas substanciais.

Meu objetivo neste estudo é demonstrar que essa virada não é a-histórica, isto é, que há uma evolução lenta e cheia de avanços e retornos por detrás dela. $\mathrm{E}$, ao final, discutir se e até que ponto essa evolução, de fato, atinge o ordenamento jurídico brasileiro.

A primeira pista para revelar essa linha evolutiva encontramo-la na Inglaterra, perto do ano 1.066.

\section{BREVE HISTÓRICO DO PRINCÍPIO DO DEVIDO PROCESSO LEGAL NA INGLATERRA}

Após ter derrotado o rei Haroldo II na batalha de Hastings, em 1066, e conquistado a ilha da Inglaterra, o conquistador Guilherme deveria ser coroado rei. Percebeu que a população inglesa tinha verdadeira adoração por um antigo monarca saxão, Eduardo, dito

${ }^{4}$ LEAL, Antônio Luiz da Câmara. Comentários ao Código de Processo Penal brasileiro, Rio de Janeiro-São Paulo: Freitas Bastos, 1942, v. 1, p. 20. 
"o Confessor", misto de rei e pastor, que foi, afinal, canonizado pela Igreja Católica menos de cem anos depois de sua morte.

O conquistador talvez estivesse cansado de tantas guerras e pretendeu construir um período de estabilidade administrativa. Além disso, não podia esquecer de que era um rei invasor. Teve de ter muito cuidado e tirocínio. Tomou diversas providências políticas que garantiram essa estabilidade por muitos e muitos anos.

Uma das providências foi de ordem litúrgica.

O conquistador foi sagrado Guilherme I em uma cerimônia solene em que confirmou as leis de Eduardo, o Confessor. É mesmo significativo que não tenha se preocupado em confirmar as leis de Haroldo II, que era um rei derrotado, mas as de Eduardo, um rei amado pelo povo.

Ao jurar as leis de Eduardo, o rei normando Guilherme I obteve diversos efeitos, alguns dos quais ele próprio talvez não tenha percebido. $\mathrm{O}$ primeiro efeito foi declarar-se a si próprio um continuador do rei saxão. Com isso, não salientou tanto sua imagem de conquistador, mas construiu uma imagem de revente continuador da tradição jurídica posta.

Outro efeito foi o de, pela primeira vez, construir um conceito que se tornaria essencial para o Direito.

Trata-se do dever do governante de não respeitar apenas as suas leis, mas também a dos seus antecessores. As leis editadas pelos monarcas anteriores se tornam, com sua morte, leis da terra (Legem Terra).

Essa tradição se transferiu aos monarcas que se seguiram a Guilherme I.
É por isso que, em 1215, os barões ingleses exigem do rei João I o respeito às leis da terra. Fazem com que ele se comprometa que "nenhum homem livre será molestado, ou aprisionado, ou despojado, ou colocado fora da lei, ou exilado, ou de qualquer modo aniquilado, nem nós iremos contra ele, nem permitiremos que alguém o faça, exceto pelo julgamento legal de seus pares ou pelo Direito da terra".

O uso da expressão "devido processo legal" (due process of the law), ocorre pela primeira vez em 1354, quando o rei Eduardo III, seguindo a velha tradição, confirma as leis da terra e, entre elas, a Magna Carta das Liberdades. O texto de Eduardo III dispõe que "que nenhum homem de qualquer estado ou condição que ele seja, possa ser posto fora da terra ou da posse, ou molestado, ou aprisionado, ou deserdado, ou condenado à morte, sem ser antes levado a responder a um devido processo legal".

Com o tempo, o poder de fazer leis do país passou do soberano ao Parlamento. E o dever de respeitá-las - que já atingia o povo passou cada vez mais a afetar o soberano.

Assim, a evolução do devido processo legal, na Inglaterra, está ligada ao poder do povo de fazer leis e ao dever de todos de respeitá-las. O Parlamento inglês representante dos comuns - é o único Poder na Inglaterra.

Hoje, o sistema jurídico inglês vive uma crise - no sentido construtivo da palavra, isto é, como ocasião de renascimento e reconstrução. Trata-se de sua integração à União Européia, fato que interferirá na concepção de que o Parlamento é o único poder político a que os ingleses devem, de fato, reverência. 
Essa integração redundará em uma modificação - muitas vezes radical - no ordenamento jurídico inglês, a fim de adaptá-lo aos contornos do Direito Comunitário europeu.

\section{BREVE HISTÓRICO DO PRINCÍPIO DO DEVIDO PROCESSO LEGAL NOS EUA}

A história dos EUA, por sua vez, conecta-se de maneira muito peculiar à história da Inglaterra.

Como primeiro ponto de ligação encontra-se a mesma tradição lingüística. Falar a mesma língua é, evidentemente, um formidável traço de união. Apenas por essa razão, aparentemente trivial, entre os EUA e a Inglaterra haverão sempre mais semelhanças que diferenças.

Outrossim, as tradições cultural e educacional estão fortemente conectadas. As universidades americanas, especialmente as mais tradicionais, são claramente influenciadas pelas universidades inglesas, especialmente Oxford e Cambridge. Para ficar com um exemplo bastante trivial dessa influência, a sede da Universidade Harvard, a mais antiga dos EUA, fica em uma cidade do estado de Massachusets chamada justamente Cambridge.

Por outro lado, os EUA viram a Inglaterra, por muitos anos, como a potência dominadora e repressora. Neste passo, é interessante sublinhar que a tradição democrática da Inglaterra não se aplicava nas relações com suas colônias.

Ofounding father Benjamin Franklin, por exemplo, relata um diálogo que teve com o primeiro-ministro inglês George Grenville em 1757, quando foi enviado a Londres para resolver problemas entre as colônias e a Inglaterra. Ouviu de Glenville o seguinte:

Vocês, americanos, têm idéias erradas sobre a nossa Constituição. Pretendem que as instruções que o rei dá a seus governadores não têm força de lei, e consideram-se livres para aceitar ou recusar essas instruções, conforme lhes parece. Mas essas instruções não são como recomendações pessoais dadas a um embaixador para ajudá-lo a conduzir-se num cerimonial pouco complicado. Em primeiro lugar, são elaboradas por juízes versados em direitos; são em seguida estudadas, discutidas, por vezes emendadas pelo Conselho; finalmente, assinadas pelo rei. Então, tornam-se a lei do país para os americanos, porque o rei é o legislador das colônias.

E segue Franklin:

Respondi a Sua Senhoria que era semelhante teoria inteiramente nova para mim. Sempre pensei que, de acordo com nossas cartas constitucionais, as nossas leis deveriam ser elaboradas por nossas assembléias e apresentadas em seguida ao rei para serem aprovadas; uma vez aprovadas, o rei não poderia mais aboli-las, nem alterá-las. E, do mesmo jeito que as assembléias não podiam fazer leis permanentes sem sua aprovação, assim também o rei não podia fazer leis sem a aprovação das assembléias. Assegurou-me que eu estava inteiramente errado. Mas não concordei". 5

Tal como hoje ocorre entre os EUA e seus satélites, a democracia é, mais do que tudo, um produto de consumo interno.

Por tal razão, as relações entre a Inglaterra e os EUA têm componentes de amor e de ódio.

No caso da tradição jurídica, a Constituição dos EUA reflete a preocupação de rompimento com certas práticas jurídicas da Inglaterra. São exemplos disso o art. $1^{\circ}$, seção $9^{a}$,

${ }^{5}$ FRANKLIN, Benjamin. "Autobiografia", apud BRUCKBERGER, R. L. A república americana, trad. de Mercedes Zilda Cobas Felgueras, Rio de Janeiro: Fundo de Cultura, 1960, p. 51-52. 
cláusula $3^{\text {a }}$, primeira parte, que proíbem as leis condenatórias (acts of attainder) e o art. $1^{\circ}$, seções 9 , cláusula $8^{a}$, primeira parte e 10 , cláusula $1^{\mathrm{a}}$, última parte, que proíbe a concessão de títulos de nobreza tanto pela União quanto por qualquer estado-membro.

No entanto, uma tradição permaneceu e conectou para sempre os sistemas jurídicos da Inglaterra e dos EUA.

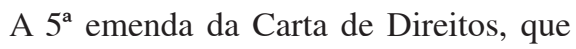
entrou em vigor em dezembro de 1791, dispôs que "ninguém (...) poderá ser privado da vida, liberdade, ou propriedade, sem devido processo legal".

Essa evolução é, porém, muito diversa da que se deu na Inglaterra. Foi radicalmente moldada por componentes políticos e étnicos que, na época da formação do princípio do devido processo legal, inexistiam na Inglaterra.

O componente político foi a existência de duas correntes durante a Convenção da Filadélfia, os federalistas e os antifederalistas. Os federalistas, representados especialmente por James Madison, Alexander Hamilton e John Jay, advogavam a adoção de um modelo federativo, em que os estados-membros abriam mão de uma parcela significativa de suas competências - especialmente a liberdade para adotar a forma de Estado e de governo, a soberania e o poder de negociar diretamente com nações estrangeiras.

Os antifederalistas, representados por George Mason, Thomas Jefferson, Patrick Henry e Richard Henry Lee, sustentavam que a nova ordem constitucional deveria assumir a forma de uma confederação de Estados independentes. Essa seria a melhor forma de preservar as tradições culturais de cada uma das antigas colônias.
A solução que se obteve foi a adoção de uma federação. Ponto, portanto, para os federalistas. Contudo, a Constituição adotada foi escrita por Jefferson e deixou de enfrentar, por exemplo, questões cruciais como a da escravidão. Ponto para os antifederalistas.

Com isso, a União foi formada sobre a idéia de que os homens - todos os homens nasceram iguais e devem como tais ser tratados. Alguns estados-membros dessa União, especialmente os do sul, seguiram com a idéia de que alguns homens nasceram para servir os demais na condição de escravos. Assim, embora aceitassem que a União dos estados-membros tivesse um estatuto de direitos humanos mais completo, não aceitavam praticá-lo em seus territórios.

O tempo passou e verificou-se um desenvolvimento econômico desigual, se comparados os estados-membros do sul e do norte. O norte desenvolveu sua economia com inúmeras indústrias. $\mathrm{O}$ sul, por sua vez, formado por estados-membros fortemente escravistas, seguiu com a economia agrícola. Estava explicada essa opção tendo em conta a utilização de mão-de-obra escrava.

Contudo, a economia do norte já exibia a vocação do expansionismo. Queria instalar indústrias também no sul, a fim de dar conta da demanda crescente. Queria vender seus produtos industrializados aos estadosmembros do sul. Contudo, os negros do sul não eram bons operários, porque não treinados. E os aristocráticos brancos do sul, naturalmente, não se sujeitariam a trabalhar como operários. Daí a dificuldade de instalar indústrias. Além disso, o potencial de compras do sul estava reduzido pelo menos à metade, pois os escravos negros estavam à margem do mercado, impossibilitados de consumir. 
Daí porque os estados-membros do norte começaram a pressionar os estados-membros do sul para acabar com a escravidão. Essa pressão se deu por meio dos órgãos de imprensa do norte, que começaram a mostrar os aspectos injustos e bizarros da escravidão.

A pressão também se deu por meio do Congresso, instalado no Distrito de Columbia, no norte do país. Os políticos e industriais do norte influenciaram o Congresso a, por exemplo, votar uma lei que proibia a importação de negros cativos da África (1808); ou a considerar pirataria, punida com a morte, essa atividade (1820).

Os conflitos - que no fundo eram conflitos sobre duas concepções do capitalismo - se acentuaram.

Atingiram um primeiro clímax em 1856, com o caso Dred Scott $v$. Sandford. ${ }^{6}$

O caso Dred Scott, como ficou conhecido, é importante por inúmeras razões.

Foi a segunda vez que a Suprema Corte estadunidense anulou um ato do congresso por inconstitucionalidade. A primeira havia sido em 1803, com Marbury v. Madison. ${ }^{7}$

Foi a primeira vez, porém, que a Suprema Corte julgou inconstitucional uma lei com base em uma visão substancial do princípio do devido processo legal.

E, por último, foi um dos fatores que desencadeou a Guerra de Secessão, tamanha foi a revolta que causou nos abolicionistas.

Dred Scott nasceu escravo no Estado da Virginia. Um de seus proprietários, o cirurgião do Exército John Emerson, levou-o consigo para o Forte Snelling, no território do Wisconsin. Estava em vigor, então, a "Lei

\footnotetext{
${ }^{6} 60$ U.S. (19 How.) 393 (1856).

75 U.S. (1 Cranch) 137 (1803).
}

do Compromisso do Missouri" (Missouri Compromise Act), de 1820, que proibia a escravidão em territórios federais acima de uma linha por ela estabelecida. Com a morte de John Emerson, sua viúva transferiu a "propriedade" de Scott para o seu irmão, John Sanford, que levou-o de volta para St. Louis. Sсотт iniciou, então, uma luta judicial para ver-se declarado livre; argumentou que com o período que viveu em território federal adquiriu a condição de "cidadão dos Estados Unidos" e, portanto, não poderia ser escravizado. Tentou, em juízo, caracterizar seu aprisionamento como um seqüestro, a privação ilícita da liberdade de um homem livre, um cidadão e portador de direitos na ordem civil. Essa ação foi inicialmente julgada procedente por um tribunal do Missouri e, depois, por um tribunal federal, não conhecida. Tornou a propor a ação e perdeu na Suprema Corte do Missouri - corte que catorze anos antes havia reconhecido a libertação de diversos escravos na mesma situação de Scott - e, posteriormente, na Justiça Federal. Conseguiu levar o caso à Suprema Corte.

O juiz-presidente Taney apresentou a decisão da Suprema Corte, com os seguintes itens: $a$ ) os fundadores dos EUA não tencionaram tratar o negro como ser humano; $b$ ) conforme a tradição do direito estadunidense, portanto, negro não é ser humano, é coisa; c) viola o princípio do devido processo legal uma lei que considerasse o negro um ser humano e, com isso, privasse alguém de sua propriedade; $d$ ) o Congresso não poderia ter editado lei que contraria a tradição jurídica dos EUA; $e$ ) a Lei do Compromisso do Missouri (Missouri Compromise Act, 1820) é inconstitucional, por violação da $5^{\mathrm{a}}$ emenda; 
f) sendo coisa, o negro não tem capacidade de ser parte; correta, portanto, a decisão que o considerou uma coisa, e não um "cidadão dos Estados Unidos".

Em sua opinão, de triste memória, o juizpresidente Taney escreveu:

A questão é simples assim: pode um negro, cujos ancestrais foram importados para este país, e vendidos como escravos, tornar-se membro da comunidade política formada e instituída pela Constituição dos Estados Unidos, e assim tornar-se titular de todos os direitos, privilégios, e imunidades, garantidas por esse instrumento ao cidadão? Um desses direitos é o privilégio de propor uma ação em uma corte dos Estados Unidos nos casos especificados na Constituição. (...) Pensamos que não, e que eles não estão incluídos, e que não se intentou que fossem incluídos, sob a palavra 'cidadãos' na Constituição, e que não podem reclamar nenhum dos direitos $\mathrm{e}$ privilégios por ela criados e garantidos aos cidadãos dos Estados Unidos. Ao contrário, eles foram naquele tempo considerados como uma subordinada e inferior classe de coisas, que foram subjugados pela raça dominante, e, ainda que emancipados ou não, continuam sujeitos à sua autoridade, e não têm direitos ou privilégios, mas apenas aqueles que o poder e o governo eventualmente lhes conferir. (...) Ninguém dessa raça jamais imigrou para os Estados Unidos voluntariamente; todos foram trazidos para cá como mercadorias. O número dos que estavam emancipados, ao tempo da elaboração da Constituição, era muito menor do que os que eram mantidos escravos; e estavam identificados, na opinião pública, com a raça à qual pertenciam, em não com a população livre. É óbvio que eles não estavam na mente dos autores da Constituição quando eles conferiram direitos e privilégios aos cidadãos de um Estado em qualquer parte do território pertencente à União. ${ }^{8}$

${ }^{8}$ TANEY, Roger B. "Opinião", em Dred Scott v. John F. A. Sandford, 60 U.S. (19 How.) 393, 403405, 411-412 (1856), em www.findlaw.com/casecode/ supreme.html (acesso em maio de 2005).
Eis aí o primeiro momento - infeliz primeiro momento - do princípio do devido processo legal.

A tensão racial cresceu e, com a eleição de Abraham Lincoln para a presidência dos EUA, os estados-membros do sul declararam a secessão e o país mergulhou em uma guerra fraticida.

Ao final da guerra, foram editadas duas emendas à Constituição dos EUA. A $13^{\mathrm{a}}$ e a $14^{\mathrm{a}}$. A $13^{\mathrm{a}}$ acaba, definitivamente, com a escravidão.

A $14^{\mathrm{a}}$ é ainda mais importante, pois afirma:

Todas as pessoas nascidas ou naturalizadas nos Estados Unidos, e sujeitas à sua jurisdição, são cidadãs dos Estados Unidos e do estadomembro onde residam. Nenhum estadomembro poderá fazer ou aplicar nenhuma lei tendente a abolir os privilégios ou as imunidades dos cidadãos dos Estados Unidos; nem poderá retirar-lhes a vida, a liberdade, ou a propriedade, sem o devido processo legal; nem poderá denegar a nenhuma pessoa sob sua jurisdição igual proteção das leis.

Essa emenda foi editada com o objetivo imediato de revogar uma antiga jurisprudência da Suprema Corte dos EUA, Barron v. Baltimore, ${ }^{9}$ para a qual a Carta de Direitos da União não se aplicava aos estados-membros. Outro objetivo, mais amplo, foi assegurar um desenvolvimento uniforme dos estados-membros.

Contudo, para que se tenha uma idéia da resistência que sofre esse conceito de submissão dos ordenamentos jurídicos estaduais ao ordenamento da União, diga-se que a Suprema Corte levou aproximadamente cem anos para começar a dar-lhe aplicação no âmbito do processo penal.

\footnotetext{
932 U.S. (7 Pet.) 243 (1833).
} 
Quanto ao devido processo legal substancial, na década de trinta do século vinte ele serviu primacialmente como ferramenta de proteção da propriedade e da liberdade, vista primacialmente como liberdade de iniciativa.

Um exemplo dessa visão privatista do devido processo legal se deu quando do período do "Novo Acordo" (New Deal), proposto e colocado em prática pelo presidente Franklin D. Roosevelt. A Suprema Corte impugnou essa política através de diversas decisões que consideraram que a intervenção do Estado na economia uma forma desarrazoada de retirada da propriedade "sem o devido processo legal". O enfrentamento entre a Corte e o presidente Franklin D. Roosevelt foi tamanho que, no início de 1937, ele elaborou e enviou ao Congresso um pacote de leis, conhecido como "Pacote da Suprema Corte" (Court Packing Plan). Esse pacote visava aposentar diversos juízes antipáticos às medidas e aumentar o números de magistrados da Suprema Corte. Assustados com essa possibilidade, os juízes da Suprema Corte passaram a, paulatinamente, diminuir a oposição ao "Novo Acordo".

Hoje, a Suprema Corte dos EUA evoluiu na sua compreensão do princípio do devido processo legal. Pode-se dizer que não o utiliza mais como um instrumento de manutenção do statu quo, como já o utilizou outrora.

Concentra-se na solução de questões relacionadas com a igualdade substancial das pessoas - o que a Constituição estadunidense denomina de "igual proteção das leis" (equal protection of the laws). A questão das políticas de ação afirmativa, as questões relacionadas com a família e outras, estão na pauta de discussões da Suprema Corte.
3 BREVE HISTÓRICO DO PRINCÍPIO DO DEVIDO PROCESSO LEGAL NO BRASIL E UMA TENTATIVA DE CONCLUSÃO

A primeira Constituição brasileira a fazer expressa menção ao princípio foi a de 1988, no inciso LIV do art. $5^{\circ}$.

Até então, conforme vimos no início desta exposição, prevaleceu, na doutrina e jurisprudência, a visão formalística do princípio.

A primeira notícia, no Brasil, do princípio do devido processo legal substancial vem com o livro "A Corte Suprema e o Direito Constitucional americano", da Professora Lêda Boechat Rodrigues, publicada em 1958..$^{10}$ Nessa notável obra, ao comentar o caso Chicago Milwaukee and St. Paul R. Co v. Minnesota, ${ }^{11}$ a querida professora carioca escreveu que, nesse julgamento, "iria a Corte converter a cláusula de due process numa restrição positiva, sustentando dever o Judiciário dar-lhe, obrigatoriamente, força executiva, sempre que os departamentos dos Estados procurassem, a seu ver, impor tarifas arbitrárias e irrazoáveis". ${ }^{12}$

E segue a grande pesquisadora, a respeito da cláusula do devido processo legal:

Ela passaria, agora, a ser instrumento ilimitado de avaliação da constitucionalidade não só das leis estaduais como das leis do Congresso, através do exame do seu acordo com a

${ }^{10}$ RODRIGUES, Lêda. A Corte Suprema e o Direito Constitucional americano. Rio de Janeiro: Forense, 1958.

${ }^{11} 134$ U.S. 418 (1890).

${ }^{12}$ RODRIGUES, Lêda Boechat. A Corte Suprema e o Direito Constitucional americano, Rio de Janeiro: Forense, 1958, p. 96. 
razão (reasonableness). Determinar o que constituía o due process transformou-se (...) na consideração mais importante do direito constitucional americano. E, uma vez que, pela aplicação da 'regra da razão' (rule of reason), a decisão judicial envolvia, na realidade, o julgamento baseado em considerações de ordem social e econômica, a cláusula do processo legal regular, entendida como proteção substantiva, atribuiu aos tribunais poder quase legislativo. ${ }^{13}$

Em 1989, pouco menos de um ano após a promulgação da Constituição cidadã, veio a lume o livro "O devido processo legal e a razoabilidade das leis na nova Constituição do Brasil", do Professor Carlos Roberto de Siqueira Castro. ${ }^{14}$ Nessa obra, que já nasceu um clássico do Direito Constitucional, defende o autor que a Constituição brasileira albergou o princípio do devido processo legal e da razoabilidade das leis.

Tenho cá minhas dúvidas de que se precisasse chegar a tanto. Com efeito, a Constituição brasileira de 1988 é em tudo diferente da Constituição estadunidense. As diferenças partem do próprio título. Enquanto é sempre necessário designar a Constituição brasileira a partir do ano de sua promulgação, tantas foram nossas aventuras constitucionais, a equivalente norte-americana foi somente uma. Seu corpo é rigorosamente o mesmo, desde 1787. Embora seja correto dizer que foi alterada inúmeras vezes desde sua promulgação, as 27 emendas ratificadas por três quartos dos estados-membros não a mutilaram.

Além disso, a Constituição brasileira é analítica e está plena de princípios e de regras.

${ }^{13}$ RODRIGUES, Lêda Boechat. Idem, p. 139-140.

${ }^{14}$ CASTRO, Carlos Roberto Siqueira de. $O$ devido processo legal e a razoabilidade das leis na nova Constituição do Brasil, Rio de Janeiro: Forense, 1989.
É discutível que devêssemos lançar mão de um único princípio, posto que amplo, para resolver todos os problemas.

E é da tradição constitucional brasileira que as leis devam obediência a toda a Constituição, tanto aos princípios quanto às regras. A diferença é que as leis podem violar as regras constitucionais e, quanto aos princípios, a violação é sempre tendencial: uma lei tende a violar um princípio.

Quanto à razoabilidade minhas dúvidas são ainda maiores. É óbvio que as leis devem ser razoáveis, como qualquer ato jurídico. A regra da razão, no sistema constitucional brasileiro, não existe senão como instrumento hermenêutico e não de construção de regras abstratas fora do Congresso.

Como o Juiz Associado da Suprema Corte dos EUA, Hugo Lafayette Black, temo que a regra da razão sirva como uma farmacopéia para que um tribunal qualquer - que, afinal, é formado por profissionais que não foram eleitos para suas funções - anule todo e qualquer ato emanado dos demais poderes que não se adapte à sua visão particular de uma questão qualquer. Não todas, mas muitas vezes, para citar o testemunho insuspeito do Juiz Hugo Black, o argumento de falta de razoabilidade das leis carece de seriedade. ${ }^{15}$ Afinal de contas, não foi com base na razoabilidade da lei que a Suprema Corte dos EUA afirmou que um negro não é gente e que qualquer lei que tenhar atribuir-lhe essa qualidade é inconstitucional?

Eu sequer penso em negar a importância de estudar e compreender a tradição

\footnotetext{
${ }^{15}$ BLACK, Hugo Lafayette. Crença na Constituição, trad. de Luiz Carlos F. de Paula Xavier e Paulino Jacques, Rio de Janeiro: Forense, 1970, p. 44.
} 
constitucional norte-americana. Essa compreensão somente se justica, porém, na medida em que servir para que possamos compreender a nossa própria.

E a primeira lição que os americanos nos passam é a importância de compreender nossas próprias origens e usá-las como baliza para os futuros caminhares. E a nossa tradição constitucional, coitadinha, é tão esquecida.

A propósito e sem o desejo de chegar a uma firme e inapelável conclusão, deixem-me fazer ao menos uma tentativa de conclusão.

Ao analisar as leis e os atos normativos públicos em face da Constituição, poderíamos à maneira dos "originalistas" ianques resgatar um belo dispositivo da nossa Constituição do Império e transformá-lo em um norte para a interpretação constitucional das leis.

Trata-se do art. 179, inciso II, que dispôs:

A inviolabilidade dos direitos civis e políticos dos cidadãos brasileiros, que tem por base a liberdade, a segurança individual, e a propriedade, é garantida pela Constituição do Império, pela maneira seguinte (...) Nenhuma lei será estabelecida sem utilidade pública.

De fato. Desde que dado o devido peso a cada uma das palavras, a questão da legitimidade da lei face à Constituição principia e se esgota nessa singela realidade. As leis são írritas se não corresponderem aos valores constitucionais. São inválidas se não atenderem à utilidade pública substancial.

Nesta época, em que inúmeros e inconfessáveis interesses privados muitas vezes se contrapõem e negam o interesse público, quando a legislação é feita aos empurrões, o respeito a esse dístico seria um notável avanço para o todo de nosso ordenamento jurídico.

\section{REFERÊNCIAS}

BUENO, José Antonio Pimenta. Apontamentos sobre o Processo Criminal brasileiro, ed. anot., atual. e compl. por José Frederico Marques, facsimilar à ed. de 1857. São Paulo: Revista dos Tribunais, 1959. p. 228.

CASTRO, Carlos Roberto Siqueira de. O devido processo legal e a razoabilidade das leis na nova Constituição do Brasil. Rio de Janeiro: Forense, 1989.

FRANKLIN, Benjamin. "Autobiografia”, apud BRUCKBERGER, R. L. A república americana, trad. de Mercedes Zilda Cobas Felgueras. Rio de Janeiro: Fundo de Cultura, 1960. p. 51-52.

LEAL, Antônio Luiz da Câmara. Comentários ao Código de Processo Penal brasileiro. Rio de Janeiro-São Paulo: Freitas Bastos, 1942, v. 1, p. 20.

PESSOA, Vicente Alves de Paula. Código do Processo Criminal, 1880, p. 20.

RAMALHO, Joaquim Ignácio. Praxe brasileira, São Paulo: 1869, pp. 5, 8, 51, 52 etc.

RODRIGUES, Lêda Boechat. A Corte Suprema e o Direito Constitucional americano, Rio de Janeiro: Forense, 1958.

TANEY, Roger B. “Opinião”, em Dred Scott v. John F. A. Sandford, 60 U.S. (19 How.) 393, 403-405, 411-412 (1856), em www.findlaw.com/ casecode/supreme.html (acesso em maio de 2005). 


\section{TÍTULO DE HONORIS CAUSA}

Oração proferida, à comunidade acadêmica, em 5 de março de 2007, pelo Prof. Dr. António José Avelãs Nunes, por ocasião do recebimento do Título de Doutor Honoris Causa da Universidade Federal do Paraná, no Salão Nobre da Faculdade de Direito.

Senhor Reitor da Universidade Federal do Paraná, Senhor Decano do Conselho Universitário, Senhores Membros do Conselho Universitário, Senhor Director da Faculdade de Direito da UFPR, Senhor Reitor da Universidade de Coimbra, Caros Colegas, Prezados Estudantes, Meus Amigos.

1 - A minha primeira palavra é, por imperativo de consciência, que não por razões protocolares, para saudar o Reitor da UFPR e, na sua pessoa, homenagear esta Universidade, a mais antiga criada no Brasil, tal como a Universidade de Coimbra é a mais antiga universidade portuguesa, talvez mesmo a mais antiga universidade pública europeia, criada que foi por acto régio de D. Dinis.

Quero dizer-lhe, Senhor Reitor Carlos Moreira Júnior, que é uma honra para mim passar a fazer parte do claustro dos doutores desta Universidade. Muito obrigado por ter acolhido a proposta da Faculdade de Direito e por tê-la apoiado junto do Conselho Universitário.

É tempo, agora, de homenagear a Faculdade de Direito da UFPR, que me habituei a considerar a minha segunda Casa. Faço-o na pessoa do seu Director, Prof. Luiz
Alberto Machado, que esteve, desde o início, entre o pequeno grupo que pôs em marcha a ideia de me ser concedido o título de Doutor Honoris Causa, ideia que defendeu perante o Conselho Universitário, em seu nome e em nome da sua Faculdade.

Devo uma palavra de reconhecimento ao Prof. Rogério Molinari, que foi relator do processo que conduziu à aprovação pelo Conselho Universitário da proposta de concessão do título de Doutor Honoris Causa. Os médicos estão habituados a lidar com casos difíceis e a salvar todos os que recorrem aos seus serviços, os bons e os maus. Perante este caso difícil, o Prof. Molinari empenhouse em salvar a minha causa, apesar dos poucos méritos dela. Aqui lhe deixo o testemunho da minha gratidão.

Uma palavra de agradecimento é devida aos Membros do Conselho Universitário, que decidiram por unanimidade outorgar-me a 
mais alta distinção universitária. A vossa decisão encheu-me de alegria, mas impôs-me um pesado encargo. $\mathrm{O}$ de ser digno da distinção que me foi concedida.

Comovidamente, aqui deixo o meu abraço fraterno a todos os Colegas desta Faculdade de Direito da UFPR, que me acompanharam ao longo do caminho que conduziu à deliberação do Conselho Universitário em razão da qual aqui nos encontramos.

Sem esquecer nenhum dos outros, que daqui saúdo com amizade, recordarei dois deles.

O Prof. Luiz Edson Fachin, por cuja mão visitei pela primeira vez esta Faculdade e a cidade de Curitiba. $\mathrm{O}$ nosso encontro foi um caso de amizade à primeira vista, que se multiplicou numa cadeia de amizades que ultrapassaram esta terra de pinhais e as fronteiras do Paraná, estendendo-se a todo o Brasil.

A Prof. a Aldacy Coutinho, a cuja amizade e generosidade devo a sementeira de ideias e de afectos que frutificou no momento feliz que hoje vivo convosco, neste edifício histórico, símbolo da Universidade e símbolo da Cidade.

A todos os meus Amigos brasileiros (alguns aqui presentes) quero agradecer o privilégio de me aceitarem como seu amigo e a honra de poder contá-los entre os meus melhores Amigos. Não vou dizer os seus nomes. Eles sabem - os presentes e os ausentes - a quem me refiro. E eu sei quanto lhes devo, no plano intelectual e no plano afectivo.

Permita-me, Senhor Reitor Carlos Moreira, uma palavra de sentido reconhecimento ao Reitor da Universidade de Coimbra,
Prof. Eng. Fernando Seabra Santos, que entendeu dever estar pessoalmente presente nesta cerimónia, num gesto que muito me sensibiliza e que diz bem do grau de exigência com que o Doutor Seabra Santos encara o seu múnus reitoral. Sublinhado o gesto do Reitor, direi ao Amigo: apesar dos meus esforços para te dissuadir de fazer a viagem, decidiste vir. Bem hajas pela tua amizade.

Não duvido de que a honra que me é concedida - a maior honra a que um universitário pode aspirar - só circunstancialmente tem que ver com os meus méritos pessoais. Na minha pessoa, quiseram V. Ex ${ }^{\mathrm{a}} \mathrm{s}$ homenagear a Universidade de Coimbra, a Universidade criada em 1290 por um rei-poeta, "plantador de naus".

Mas o simples facto de terem V. Ex ${ }^{a}$ s entendido que eu poderia ser o pretexto para esta homenagem à Universidade de Coimbra é uma distinção que eu só mereço por uma razão: porque $\mathrm{V}$. $\mathrm{Ex}^{\mathrm{a}} \mathrm{s}$ assim o decidiram. Não posso cometer a indelicadeza - que seria, ainda por cima, ingratidão - de pôr em causa a justeza da vossa decisão. Aceito-a com toda a humildade, invocando - e já não é pouca imodéstia da minha parte - o dito de um personagem de Saramago: "conheces o nome que te deram, não conheces o nome que tens". Eu sei apenas o nome que os meus pais me deram, não conheço o nome que tenho, não conheço a ideia que os outros fazem de mim.

Do fundo do coração, agradeço a vossa generosidade para comigo. E fico-me por aqui em matéria de agradecimentos. Porque acredito que, "em assuntos de sentimento, quanto maior for a parte de grandiloquência, menor será a parte de verdade". (José Saramago) 
2 - Se eu fosse Fernando Pessoa/Bernardo Soares, saberia "dar a cada emoção uma personalidade, a cada estado de alma, uma alma”. Mas não sou. Por isso, fiel à cultura camponesa da minha terra, vou tentar contarvos algumas histórias.

Em 1985, coube-me o privilégio de fazer o elogio académico de Tancredo Neves, recémeleito Presidente do Brasil, na cerimónia solene do seu Doutoramento Honoris Causa pela Faculdade de Direito da Universidade de Coimbra. Saudei-o como descendente de portugueses dos Açores que se manteve fiel aos ideais democráticos. Mas nele saudei, jubilosamente, o povo brasileiro que acabara de se libertar da ditadura.

Na parte final da cerimónia, ostentando já o anel, a borla e o capelo de Doutor em Direito, Tancredo Neves tomou o seu lugar nos cadeirais, junto de mim. Com ar cansado, muito comovido, segredou: "Valeu a pena ter chegado até hoje, só para viver este momento".

Perante vós, nesta Sala dos Actos Solenes, é o que me apetece dizer, não em segredo, mas em voz alta.

3 - Chegado aqui, poderia apresentarme como o fez José Saramago no discurso que proferiu ao receber o Prémio Nobel da Literatura, no qual contou histórias dos avós pastores de porcos, com os quais viveu a infância. Também eu poderia falar dos meus avós analfabetos, moleiro um, pastor de cabras o outro. E falar do meu pai alfaiate e da minha mãe costureira. Esta é a minha linhagem. Estas são as minhas raízes, raízes fincadas no povo "que trabalha dia e noite sem esmorecer", no povo que faz a história mas "não cabe nas crónicas" dos historiadores
(Miguel Torga), "gente cujo rosto / Às vezes luminoso / E outras vezes tosco / Ora me lembra escravos / Ora me lembra reis", para utilizar os versos com que uma poetisa portuguesa (Sophia de Mello Breyner) caracteriza o povo português.

Poderia falar-vos dos meus cinco tios que tiveram de emigrar para o Brasil e por cá morreram brasileiros, quase tão pobres como quando chegaram, deixando por cá filhos, netos e bisnetos.

Poderia contar-vos a história do meu próprio pai, que, em meados do século passado, tentou também ele a sua sorte em terras brasileiras, sorte madrasta que o obrigou a regressar a casa, mais pobre e mais sofrido do que quando dela partira.

O sangue brasileiro é, pois, sangue do meu sangue. Este parentesco faz-me feliz e quase me autoriza a considerar-me brasileiro por direito próprio.

4 - Mas esta é uma memória que pouco vos interessa. Talvez valha a pena, porém, recordar aqui uma outra memória, a memória de um "tempo carcerário" (Orlando de Carvalho), um tempo em que a Pátria era "lugar de exílio" (Daniel Filipe), um tempo de raiva, em que os poetas tinham "remorsos da beleza", invectivavam o sol, por "nascer todos os dias / no emprego burocrático de dar razão aos relógios", um tempo em que, mais uma vez nos versos de José Gomes Ferreira, os poetas faziam "versos contra a Paisagem do mundo / - essa prostituta que parece andar à ordem dos ricos para adormecer os pobres".

Nesse tempo salazarento, concluí em 1962 a minha licenciatura em Direito, vivendo de bolsas de estudo desde os quinze 
anos. O meu projecto de então era ser juiz. Barraram-me o caminho por razões políticas. Pouco depois, recusei um lugar de quadro superior num banco por preferir a carreira académica. A polícia política conseguiu adiar o meu contrato até 1967. E só cedeu perante a acção determinada do Director da minha Faculdade, talvez a única Escola portuguesa que, durante aqueles anos de chumbo, fez ponto de honra em não recusar ninguém por razões ideológicas.

Como norma de trabalho, creio poder dizer que segui à risca o conselho de Fernando Pessoa/Ricardo Reis (Odes): "Sê todo em cada coisa. Põe quanto és / No mínimo que fazes". Mas foi o conselho de um grande Mestre da minha geração, o Doutor Orlando de Carvalho, que mais profundamente marcou a minha atitude de universitário: "Faça-se respeitar tal como é. Para isso é preciso pisar os terrenos do adversário", disse-me ele quando entrei na Faculdade como segundo-assistente. E assim procurei fazer, ao longo dos anos.

5 - Com o início da guerra colonial, a opressão agravou-se em Portugal. Em 1969, os estudantes da UC, em protesto contra o regime, contra a guerra e contra a opressão, fizeram greve a exames, com uma adesão superior a 90\%. O governo abanou e o ministro foi substituído. Uns tempos depois, o novo ministro anunciou reformas que sofreram forte contestação dos sectores mais à direita dentro da Universidade. Num relatório apresentado ao Senado universitário o Director da minha Faculdade criticava duramente aquelas reformas e insinuava que as coisas já tinham ido longe demais, que algumas cátedras estavam a ser utilizadas para 'propaganda' de ideias marxistas.

Entendi - creio que correctamente - que a conversa era comigo. E decidi publicar numa das revistas da Faculdade, com a concordância do respectivo Director, um capítulo das minhas lições de Economia Política em que era clara a influência marxista. O texto saiu depois em livro, sob o título "Os sistemas económicos”. Estávamos em meados de 1973. Não me aconteceu nada, a não ser, porventura, algumas anotações mais na minha ficha na polícia política.

6 - Entretanto, com a Revolução dos Cravos (25 de Abril de 1974), chegou o dia em "emergimos da noite e do silêncio" (Sophia), uma longa noite de 48 anos. Estava desde Setembro/1973 em Paris a preparar a minha tese de doutoramento. Fui a Portugal ver a festa. E já não regressei, mobilizado que fui para integrar o $1^{\circ}$ Governo do Portugal liberto do fascismo. Esse foi o meu trabalho, responsável pelo Ensino Superior e Investigação Científica, até Setembro de 1975. Com a queda do último Governo presidido pelo General Vasco Gonçalves, regressei a Coimbra e à Faculdade de Direito. Os tempos conturbados da contra-revolução 'obrigaramme' a dedicar boa parte do meu tempo e das minhas energias a actividades cívicas que foram adiando o meu doutoramento. Afinal, “ a vida é o que fazemos dela”, como escreveu Fernando Pessoa...

Concluída, finalmente, a tese em Julho de 1983, prestei provas em Maio de 1984. Pois bem. Apesar das "portas que Abril abriu" (Ary dos Santos), neste Maio dez anos depois de Abril, corri o risco de ficar reprovado, de novo por razões políticas. 
A minha tese estuda a problemática do desenvolvimento na América Latina, particularmente no Brasil. Pois um dos arguentes (exterior à Universidade de Coimbra) foi a ponto de inventar um autor argentino - que depois confirmei nunca ter existido! - para me acusar da ignorância grave de desconhecer o principal adversário de Raul Prebisch, o grande economista argentino, primeiro Director da CEPAL, cujas ideias analisei na minha tese. Tudo isto para votar a minha reprovação.

$\mathrm{Na}$ tese, defendia, em síntese, que o único desenvolvimento digno desse nome é o "desenvolvimento do povo, pelo povo e para o povo". E concluía perguntando se um tal desenvolvimento poderá ocorrer no quadro do capitalismo. Terminava deste modo as mais de mil páginas da tese, editada no México pelo Fondo de Cultura Económica e recentemente editada no Brasil pela Quartier Latin, com prefácio de Celso Furtado (o último escrito do grande jurista/economista brasileiro, que aqui recordo, carinhosamente, como um dos meus Mestres): "Por nós, defendemos que a via socialista é aquela que permite a mais eficaz mobilização dos recursos disponíveis para a prossecução dos objectivos enunciados, garantindo uma distribuição mais igual de sacrifícios e benefícios. Acreditamos, com Teixeira Ribeiro - Catedrático de Coimbra com quem sempre trabalhei -, que "o socialismo realizado mostra ser uma técnica eficiente de desenvolvimento de países pobres".

Talvez por isso, um outro membro do júri (também exterior à Universidade de Coimbra) votou a minha reprovação alegando na sua declaração de voto que eu era um cientista comprometido, pelo que não tinha lugar na Universidade. Assim mesmo, como quem diz: cá se fazem, cá se pagam.

7 - Obtido, nestas condições, o título de Doutor, o Conselho Científico da minha Faculdade deliberou, por unanimidade, a minha contratação como professor, o que me permitiu continuar na carreira universitária. Por unanimidade viria também a ser aprovado no concurso para professor associado.

Anos mais tarde, quando me apresentei a provas públicas para obter o título de agregado, o professor que tinha querido reprovar-me por eu ser um cientista comprometido, era professor catedrático da minha Faculdade e, segundo as praxes, seria o arguente da lição de síntese que eu teria de apresentar publicamente, nos termos da legislação que regula as provas de agregação. Entendi, por isso, ser meu dever deixar claro que eu era mesmo um cientista comprometido, para ser julgado como tal.

$\mathrm{Na}$ minha lição (que publiquei em livro logo a seguir) defendi a tese de que a Economia Política surgiu como "ciência da burguesia", comprometida com a acção da burguesia revolucionária no sentido de acelerar a desagregação da ordem feudal e de erguer a nova ordem burguesa, do mesmo modo que a teoria económica marxista (enquanto Crítica da Economia Política) se assumiu como "ciência do proletariado", comprometida com a transformação do mundo, empenhada em "dar à classe operária (...) a consciência das condições e da natureza da sua própria acção". (Engels)

Defendi que a ciência económica sempre esteve, desde as origens, comprometida com um determinado projecto de sociedade. Foi assim com os fisiocratas, com Adam Smith 
e com David Ricardo. Foi assim com Karl Marx. Foi assim com Keynes, cuja obra teórica visou, confessadamente, salvar o capitalismo da derrocada que parecia iminente, perante as ondas de choque da Grande Depressão e os horrores do nazifascismo, já por demais notórios.

Aí fiz uma crítica cerrada do paradigma marginalista, dos seus pressupostos ideológicos, da sua pretensa neutralidade científica, da sua concepção de "economia pura", de "ciência físico-matemática”, "com o mesmo grau de certeza que possui a mecânica racional". Procurei mostrar a sua incapacidade para compreender o capitalismo, e critiquei a sua recusa em analisar o poder, as estruturas do poder, as relações de poder. Defendi que o mercado é, como o estado, um produto social, uma instituição política, e não um mecanismo natural.

Para concluir que a ciência económica é uma ciência política, comprometida com valores.

Pois bem. Exprimindo-se por voto secreto (prática estranha na comunidade universitária, que deveria primar pela transparência), o júri deliberou aprovar-me por unanimidade, ou seja, com o voto favorável do professor que votara a minha reprovação no doutoramento por eu ser um "cientista comprometido". O mesmo viria a acontecer no concurso para professor catedrático, pouco tempo depois.

Tinha conseguido aquilo que me propusera: usar plenamente a liberdade de investigar e de ensinar; não abdicar nunca deste direito essencial à função de professor; ocupar o meu lugar na Universidade sem renegar as minhas ideias.

Tinha aprendido o vero alcance da verdade contida nestes versos de Pessoa
(Odes, Ricardo Reis): “A realidade / Sempre é mais ou menos / Do que nós queremos / Só nós somos sempre / Iguais a nós próprios”.

8 - Dito isto, creio ser meu dever dizer aqui que, mesmo nos anos de chumbo do fascismo, a Faculdade de Direito de Coimbra procurou afirmar-se como uma Escola plural, uma Casa de Cultura, uma Casa de Liberdade, uma Casa onde o confronto das ideias e a tensão da polémica não excluíam o respeito recíproco, uma Casa onde se praticava a "liberdade de aprender e de ensinar" que a Constituição do Portugal Democrático a todos veio garantir. A este propósito, deixem-me contar só mais uma pequena história.

Em 1972, as circunstâncias ofereceramme a feliz oportunidade de publicar em livro uma nota minha de crítica ao conteúdo de uma entrevista de Jan Tinbergen (pouco antes galardoado com o Prémio Nobel da Economia), seguida de um artigo de resposta de Tinbergen e um artigo meu, de maior fôlego (objecto de cortes vários da Censura, na revista onde foi originariamente publicado), criticando de novo, na perspectiva do marxismo, as concepções social-democratas defendidas por Jan Tinbergen.

Chamei ao livro "Do capitalismo e do socialismo". Acontece que esse livro foi lido pelo Doutor Antunes Varela, regressado ao seu lugar de Professor da Faculdade de Direito de Coimbra, após vários anos de ministro do governo de Salazar. Era ele o Ministro da Justiça quando fui impedido de me candidatar à magistratura. No entanto, como professor da FDUC e apesar de eu não lhe ter oferecido o livro, o Doutor Antunes Varela escreveu-me uma carta em que, para 
além de outras referências elogiosas, concluía deste modo:"Apesar da ideologia colectivista que o perpassa de princípio ao fim, este livro honra o seu autor e a Escola que o formou".

Trago-vos esta história, não para me elogiar, mas para homenagear a minha Faculdade, que gosto de recordar assim: plural, tolerante, aberta ao diálogo. É por isso que gosto dela. É por isso que gosto também da minha nova Casa: a Faculdade de Direito da UFPR.

9 - Vivemos um tempo de grande esperança e de grande desespero.

Um tempo de grande desespero. Porque sabemos - lembrou-o a FAO há pouco - que cerca de 18 mil crianças morrem de fome todos dias; que 850 milhões de pessoas deitam-se diariamente sem nada no estômago; que o número de pessoas com fome aumenta ao ritmo de cinco milhões por ano.

$\mathrm{E}$, no entanto, todos sabemos que a humanidade dispõe hoje de recursos para evitar este escândalo intolerável. Pesa sobre nós, universitários-cidadãos, pesa sobre a Universidade-cidadã uma enorme responsabilidade. Digo-o com a força dos versos de uma grande senhora da poesia portuguesa (Sophia de Mello Breyner): "Vemos, ouvimos e lemos. / Não podemos ignorar".

Um tempo de grande esperança também. Porque a revolução científica e tecnológica tem proporcionado fabulosos ganhos de produtividade, que parecem tornar mais real a utopia dos clássicos do marxismo ao assumirem que, um dia, a humanidade há-de passar do reino da necessidade para o reino da liberdade. Sei bem - sabemos todos - que esse dia não será amanhã. Mas talvez tenhamos razões para acreditar que estamos a fazer o caminho. Porque o caminho do futuro do Homem passa pela educação, pelo progresso científico, pela democratização do conhecimento e não pela contra-revolução monetarista e neo-liberal que inspira a política de globalização, que muitos procuram identificar com a revolução científica e tecnológica.

Cabe-nos a nós, universitários, trabalhar para fazer luz nesta noite do "pensamento único" e do "fascismo de mercado" (Paul Samuelson). E não podemos esperar muito mais. Porque, dizendo-o com versos de Xico Buarque, "quem espera nunca alcança".

10 - Termino com um haikai de Helena Kolody:

\section{"Sou voz mínima / cantando / no coral do mundo".}

Bem hajam todos por terem querido encontrar um lugar para mim no vosso coral. Bem hajam todos por me terem ouvido. Perdoem-me pelo tempo que lhes roubei.

Curitiba, 5 de Março de 2007 